Intersections

Canadian Journal of Music

Revue canadienne de musique
Intersections CANADAN TOURAA OP NUSIC

\title{
David Schroeder. 2013. Experiencing Mozart: A Listener's \\ Companion. Lanham, MD: Scarecrow. 236 pp. ISBN \\ 9780810884281
}

\section{Roseen Giles}

Volume 34, numéro 1-2, 2014

URI : https://id.erudit.org/iderudit/1030881ar

DOI : https://doi.org/10.7202/1030881ar

Aller au sommaire du numéro

Éditeur(s)

Canadian University Music Society / Société de musique des universités canadiennes

ISSN

1911-0146 (imprimé)

1918-512X (numérique)

Découvrir la revue

Citer ce compte rendu

Giles, R. (2014). Compte rendu de [David Schroeder. 2013. Experiencing Mozart:

A Listener's Companion. Lanham, MD: Scarecrow. 236 pp. ISBN

9780810884281]. Intersections, 34(1-2), 212-216.

https://doi.org/10.7202/1030881ar

Copyright @ Canadian University Music Society / Société de musique des universités canadiennes, 2015
Ce document est protégé par la loi sur le droit d'auteur. L’utilisation des services d’Érudit (y compris la reproduction) est assujettie à sa politique d'utilisation que vous pouvez consulter en ligne.

https://apropos.erudit.org/fr/usagers/politique-dutilisation/ 
to the broader historiographical narrative of twentieth-century music. Perhaps this vibrant contribution to his memorialization will make it so.

\section{WORKs Cited}

Carr-Boyd, Ann, and Alan Blyth. 2003. "Tintner, Georg," in Grove Music Online. Oxford University Press. http://www.oxfordmusiconline.com/ subscriber/article/grove/music/27998.

Levi, Erik, and Florian Scheding, eds. 2010. Music and Displacement: Diasporas, Mobilities, and Dislocations in Europe and Beyond. Lanham, MD: Scarecrow.

Williamson, John. 2004. "Conductors and Bruckner." In The Cambridge Companion to Bruckner, ed. John Williamson, 229-43. Cambridge: Cambridge University Press.

Wurz, Mattias. 2012. "Book Review: Out of Time. The Vexed Life of Georg Tintner, by Tanya Buchdahl Tintner," Vienna Review, 25 October. http:// www.viennareview.net/vienna-review-book-reviews/book-reviews/ georg-tintner-when-a-composer-conducts-his-life.

Colleen Renihan

David Schroeder. 2013. Experiencing Mozart: A Listener's Companion. Lanham, MD: Scarecrow. 236 pp. ISBN 9780810884281.

David Schroeder's Experiencing Mozart: A Listener's Companion is the first of two instalments in the Listener's Companion series by Scarecrow Press released this year, along with Robin Maconie's Experiencing Stravinsky (2013). This series, aimed at non-specialists, addresses the basic yet ever-complex issue of listening to music meaningfully. Using accessible and engaging language, the series seeks to help readers with a variety of musical backgrounds to achieve a deeper understanding of music's social significance by tracing a history of listening. In his foreword to this volume series, editor Gregg Akkerman writes that this task is "accomplished in an inclusive manner that does not necessitate extensive musical training or elitist shoulder rubbing" (ix). Schroeder's book is extremely easy and indeed delightful to read, presenting some of Mozart's greatest works in a manner that is original, accessible, and without hint that the author has "dumbed things down" for a non-specialist audience. By far the most interesting aspect of this series, and Schroeder's contribution in particular, is the focus on the listener's experience, both current and historical, and the creativity that this inspires in a non-academic context: "By positioning readers in imagined listening environments that inform and explain this music's genesis and performance, authors can teach readers-who are also listeners-how to enjoy and appreciate much more deeply the genius behind the art" (ix). Schroeder's intended audience is broad and inclusive. As an introduction to the works of Mozart, this volume is equally appropriate as a 
supplement for a course on classical music, and for a student of any level wishing to begin a study on Mozart's music.

Schroeder has organized the volume into chapters that proceed generally in chronological order, beginning with Mozart's early years in Salzburg (chapter 1, "Marching Bands, Church Music, and Escape from Salzburg") and ending with The Magic Flute and Requiem (chapter 9, "A Fellow Prankster and a Strange Commission: The Magic Flute and Requiem"). The author has further subdivided each of the chapters into smaller sections of no more than a few pages, making this book ideal for those who wish to find out more about particular pieces or genres without committing to a long reading session, and hopefully punctuating their time with the book with some listening. Schroeder's "You Were There" sections describe quasi-fictional situations that place the reader in a performing context, both in Mozart's time and in our own, effectively describing how Mozart's music was heard both then and now. The novelistic writing of these sections is a pleasure to read, and although the author uses the facts as starting points for imaginative storytelling, he makes it clear that his intention with these passages is not to write an objective history and that he hopes "that these will be taken in the spirit of good fun in which they are intended" (xv).

As much as Experiencing Mozart is tailored for the average listener, I do not wish to imply that this approach is achieved at the expense of scholarly rigour. Schroeder's reputation as a scholar of classical music is, as Akkerman notes, "unimpeachable" (x), demonstrated unequivocally by his monumental contributions to the history of music in such volumes as Haydn and the Enlightenment: The Late Symphonies and Their Audience (1990) and Mozart in Revolt: Strategies of Resistance, Mischief and Deception (1999). The success of Schroeder's latest book is that he presents Mozart's music in a way that does not diminish its complexity, both formally and historically, and communicates it in the clearest of language. Thus, Schroeder writes in a style that avoids alienating any part of his readership: on the one hand it is not too technical or overly specific for the average music lover, and on the other, it is insightful and refreshing so as to remain interesting for music scholars, in particular, for its potential application in the classroom. The author's quirky way of dropping hints about juicy bits of intrigue, especially by referring to plot lines and techniques discussed in the later chapters on Mozart's operas, keeps anyone reading, regardless of musical background. Indeed, Schroeder implies on several occasions that one of his primary goals is to "convey the excitement that [he feels] about the works ... [by] setting up as few roadblocks as possible to readers wishing to share in that enjoyment" (xii).

The fact that the author focuses on a select few of Mozart's works, as opposed to attempting to cram in as many as possible, demonstrates an enlightening new approach to listening guides in general, one that is in many ways more effective since it is based primarily in the construction of stories. In his advice to listeners presented in the introduction, Schroeder addresses a key issue that can drastically affect someone's listening experience: the selection of recordings. Without implying that certain approaches to the interpretation 
of classical music are necessarily better than others, Schroeder provides an extensive but not overwhelming listening list at the end of the book (which is also accompanied by a selected reading list and a detailed glossary). $\mathrm{He}$ then counsels his readers above all to listen to as many recordings of the same piece as they can so that they may be able to discover their own taste in music, and also to realize the extent to which interpretation can have on the overall work. In a time when "greatest hits" CDs, which occasionally offer a somewhat skewed perspective, tend to be the cheapest option when selecting recordings, Schroeder's advice is both sound and timely.

Experiencing Mozart opens by posing the question obvious to many who see "classical music" (a genre designation that has unfortunately come to encompass most music using strings or orchestra) as incapable of speaking to contemporary audiences. Schroeder proposes that classical music, Mozart in particular, is relevant and even crucial for modern culture, with which he follows, "The purpose of this book is to show how that can be so, not casting Mozart as a museum piece from a bygone century but as someone who cared about many of the issues that remain as pressing to us now as they were to his audiences then, as someone who speaks to us with a perceptiveness that has not dulled in the least over time" (xi). As an initial way in to Mozart and his music, Schroeder's thoughtful selection of quotations from Mozart's letters reveals the playful aspects of the composer's character, which may come as a pleasant surprise to many readers unfamiliar with Mozart's biography. Brilliantly weaving historical facts with imagined stories, and modern realities with eighteenth-century life, the author then embarks on more detailed descriptions of a well-picked selection of Mozart's works.

In chapter 2, "The Shadow of Haydn: Symphonies," Schroeder takes an approach to the explanation of musical form that is at once based in the modern listeners' experience of musical organization, and also linked to a central tenet of eighteenth-century music, that form is "not something abstract which is imposed on the music but ... it is meant to be heard" (23). Beginning with Haydn before moving on to Mozart, Schroeder explains that classical form is built primarily on aural cues. These markers, which are written to be heard, create the logic of classical music (ca. 1750-1820) and are by no means part of an abstract code that can be understood only with a high degree of musical literacy. Although Schroeder indicates early on that the ability to read music is not a prerequisite to understanding this book, some score excerpts, or even schematic diagrams without actual musical notation, would have been useful here. Schroeder's descriptions of musical form are clearly and simply expressed; however, with a single exception (154), the book includes no figures, images, or score examples, which in many cases could have been informative. Lastly, Schroeder's description of musical form in Mozart's concertos (in chapter 5, "Virtuoso Performer: Concertos") addresses the difficult task of hearing and understanding the "drama" of abstract pieces of music without the analogy of sonata form. His solution is to think of the concertos not as absolute music (a term clearly defined in the glossary) but rather as narratives that can simultaneously present alternate endings to the same story. His point of reference is 
apt and may be familiar to readers: Tom Tykwer's 1998 film Run Lola Run (in German. Lola Rennt), which provides a variety of outcomes for the same mis en scène. Casting Mozart as a storyteller, Schroeder writes, "One suspects that had Mozart lived two centuries later he might have been a great filmmaker, not only because of the cinematic nature of his operas, but, in a more abstract way, because of his concertos as well" (80).

Experiencing Mozart provides detailed synopses of Mozart's most performed operas, The Abduction from the Seraglio (1782), The Marriage of Figaro (1786), Cosi fan tutte (1790), Don Giovanni (1787), and The Magic Flute (1791), and also presents a simple yet profound way for most listeners to understand the relationship between the librettist's words and Mozart's music (chapters 4, 7, and 8: "In the Realm of Joseph II: The Abduction from the Seraglio," "Revolutionary Thoughts about Women and Power: Figaro and Cosi," and "Carnival versus Lent: Don Giovanni," respectively). Going one step further with the characterization of Mozart as a filmmaker, Schroeder's chapters on the operas constantly press a singularly important point: that the music Mozart gives to each character can in many cases tell you more about motivations and personality than do actions and words alone. For example, by focusing on the profound struggle between the genders critiqued by Mozart in The Abduction, Schroeder suggests that while the story alone does not overtly imply the superiority of either sex, Mozart's music casts the female characters in decidedly stronger roles: "In this and the operas to follow it is imperative that we do not simply follow the words of the librettos, which may be ambiguous on this and other points, but listen carefully to the quality and nature of the music that Mozart provides, where strength of character can be defined" (69).

Schroeder's final chapter, "Coda: From Then to Now," addresses Mozart's lasting influence on modern culture, in particular upon playwrights, novelists, filmmakers, and others who are not necessarily composers or musicians. By highlighting the importance of Mozart's legacy within the art and literature of modern times-most notably in the writings of Alexander Pushkin, Søren Kierkegaard, and George Bernard Shaw-Schroeder further stresses the point that music is much more than a pleasantry relevant only to those who practise it, but is rather a pervasive and extremely significant cultural force, equally important for non-specialists and for non-musicians. He writes, "Praise from musicians is one thing, but it is entirely different when it comes from non-musicians who themselves are extraordinary achievers and genuinely understand [Mozart], or represent him in entirely unique ways that speak directly to the people of their time. I can find no better way to emphasize my goal in this book, which is to make Mozart relevant to us in the twenty-first century" (187). That music acts as an underpinning for human culture may seem obvious to some, but the incorporation not only of reception history, primarily relevant to scholars, but also of a composer's "renown" - a general term used by Mark Everist to denote the lasting significance a composer has, in particular for non-specialists 
(Everist 2012, 17) 1 -are two factors that together make up the cultural history surrounding the life and works of a given composer. Schroeder's contribution therefore not only seeks to "make Mozart relevant to us in the twenty-first century" but also casts the net much wider in the writing of composer histories.

\section{WORK Cited}

Everist, Mark. 2012. Mozart's Ghosts: Haunting the Halls of Musical Culture. New York: Oxford University Press.

Roseen GiLes

John Beckwith and Robin Elliott, eds. Mapping Canada's Music: Selected Writings of Helmut Kallmann. Waterloo: Wilfrid Laurier University Press, 2013. 281 pp. ISBN 978-1-55458-891-6.

Helmut Kallmann is a pivotal figure in Canadian music studies and his passing in 2012 marked the end of an era that, in essential respects, he defined through more than a half-century of research on musical activities in Canadian music history. Mapping Canada's Music: Selected Writings of Helmut Kallmann ${ }^{2}$ is a collection of seventeen writings by Kallmann, a dozen of which have been previously published, and five presented in this volume for the first time. Among these are texts by Kallmann on historiographic perspectives related to Canadian music, including accounts of seminal publications such as Kallmann's $A$ History of Music in Canada 1534-1914 and the Encyclopedia of Music in Canada, and discussions of his work with institutions that contributed toward the rise of Canadian musical studies in the twentieth century, such as the Canadian League of Composers and the music division of the National Library of Canada. In addition, there are autobiographical writings by Kallmann that give the reader insight into the life story that shaped Kallmann's outlook and motivations. It is fitting that the editors of this volume are John Beckwith and Robin Elliott, ${ }^{3}$ both eminent scholars of Canadian music in the tradition of Kallmann. In the opening of the book's preface, Beckwith and Elliott explain that they first had the idea to recognize Kallmann's work in Canadian music by

1 Everist's study is a fresh look at Mozart reception and is also a nuanced study of the persistent and occasionally overlooked influence that Mozart has had on contemporary culture. Interestingly, Everist distinguishes two factors that make up Mozart's underlying societal significance: firstly reception, which is found chiefly in the scholarly realm, and secondly, renown, "a loose term, related to reputation, significance, and a host of other concepts that attribute value to cultural artifacts and their producers" (17), which resonates particularly with non-specialist readers of music literature.

2 The choice of the "map" metaphor for the book's title is an apt one. Readers will learn in various places through these writings of Kallmann's lifelong love of maps, reflected in telling ways in his approach to research and the representation of historical paradigms in Canadian music history in his publications.

3 John Beckwith was the inaugural Jean A. Chalmers Chair of Canadian Music and director of the Institute for Canadian Music at the Faculty of Music, University of Toronto, from 1984 until his retirement in 1990, and Robin Elliott is the current Jean A. Chalmers Chair and director of the ICM, a position he has held since 2003 . 